\title{
THE ALKALI INDUSTRY OF GREAT BRITAIN: CENTENARY OF A CHEMICAL COMMUNITY
}

\begin{abstract}
$\mathrm{T}$
HERE has appeared recently a historical account of the "Chemical Industry in Widnes"*, a book of singular attraction to any interested in the fluctuating fortunes of the Leblanc soda-ash process ; or in the development of any large and interwoven group of chemical industries through a long sequence of changing years and circumstances ; or, indeed, in the wider aspects of the influence upon a district, originally purely agricultural, of more than a hundred years of development of fundamentally important and massive chemical manufactures at its centre. Such is the history of Widnes, and by good fortune a man of diverse qualities was at hand to write it : for the author, Dr. D. W. F. Hardie, a member of the Widnes Research Laboratory of Imperial Chemical Industries, Ltd., General Chemicals Division, is not without distinction as a man of letters and a novelist. Moreover, he has obviously been inspired by the theme of the chemical industry of Widnes to prosecute careful and extensive research into the details of its history, so that union in one person of a conscientious historian, a scientific outlook, and unusual literary ability has produced a record which is both authentic and captivating.
\end{abstract}

Widnes, little more than a hundred years ago, was a hamlet on the north bank of the River Mersey. Between it and Liverpool, some twelve miles to the north-west, stretches an area of mainly flat country with alluvial soil well adapted to arable and pasture farming and to market gardening. Opposite Widnes the River Weaver enters the Mersey after a circuitous course past Winsford and Northwich (centres of the Cheshire salt mines) around the sandstone hills and bluffs which lie between the salt beds and the Mersey, and which stand in contrast to the uniformly flat country of south Lancashire on the other side of the Mersey. Thus in the late eighteenth and early nineteenth centuries, Widnes and its surrounding district were at the centre of a purely agricultural area, the nearest towns of any size being the port of Liverpool to the west; to the east, the town of Warrington, where the main road from the south to Carlisle crosses the Mersey; and, to the north, the township of St. Helens, which became industrialized somewhat earlier than Widnes.

Dr. Hardie states that the early attempts to manufacture soda from salt were sited in Liverpool, but that it was soon realized that the complexity of the Leblane process demanded more space than was conveniently available in an already developed mercantile town and port. In particular, the quantities of sulphuric acid needed for the first stage of the process - the conversion of salt into 'salt cake' (acid sodium sulphate) - necessitated the manufacture of vitriol by the chamber process on a very large scale. So it came about that first John Hutehinson in 1847, and some years later James Muspratt, set up independent works at Widnes to produce alkali, sulphuric acid and, as time went on, other 'heavy' chemicals; while similar factories were also commenced in the neighbourhood by others. Widnes

* A History of the Chemical lndustry in Widnes. By Dr. D. W. F. Hardie. Pp. xii $+250+38$ plates. (Liverpool: Imper
Industries. T.td., General Chemicals Division, 1950.) 218. came to be selected, no doubt, not only because of available space but a!so because its situation opposite the confluence of the Weaver with the Mersey was singularly convenient for delivery by water transport of the primary raw material needed for alkali manufacture-salt from Northwich and Winsford.

There is no need here to dwell upon the many outstanding figures in chemical industry who were intimately connected with Widnes during the latter half of the nineteenth century-Muspratt, Gossage, Gaskell, Deacon, Hurter, Henry and John Brunner and the rest: Dr. Hardie has given a complete picture of all these and of their individual contributions to the building of a great industry. He has also gone deeper into personal aspects, showing how in numerous instances the foremen and workmen of the old independent firms maintained contact with them, not only themselves, but often in their sons and grandsons; so that, as the late Sir Frederick Bain says in his foreword to Hardie's book, Widnes "can still hear the talk of its fathers, grandfathers and greatgrandfathers" and "possesses at this time the great treasure of continuity". Hence, although the old independent alkali firms of Widnes merged in 1890 into the United Alkali Company to fight for survival against the ammonia-soda and electrolytic alkali processes, and all these eventually in 1926 became part of Imperial Chemical Industries, Ltd., there are still many descendants of the workers in the original constituent firms of the United Alkali Company occupied in the manufacturing plants of its present-day counterpart, the General Chemicals Division of Imperial Chemical Industries, Ltd. There has thus arisen at Widnes, side by side with the agricultural community which still exists as formerly outside the town itself, a distinctively chemical community derived, it is true, to some degree from the local agricultural families, but doubtless to a much greater extent from beyond the area.

The manner in which, in many instances, successive generations of workers have elected to follow employ. ment in the same concerns as their forbears, although of course not peculiar to the Widnes chemical industry, is nevertheless an asset of definite value to any com. mercial undertaking. At Widnes, it perhaps had its roots in the original circumstances of a number of completely individual firms, each of relatively small size by present-day standards. It seems doubtful whether such continuity, or rather the motives underlying such continuity, may be expected to be seen in the employees of the vast modern undertakings, in which contact between the higher levels of management and direction and the foremen, charge-hands and process workers is bound to be so much less personal and direct. Perhaps, unless great care is taken to conserve this element of personal interest, modern developments will result in the loss of a Victorian relationship between good employers and good employees - a loss not wholly to be compensated by the advantages gained for the workers of the twentieth century in other ways.

However this may be, there is another aspect of the developments at Widnes (and elsewhere) in the mid-nineteenth century which was not so admirable, 
and which provides an oxample to be avoided. Byproducts of the chemical processes in use, notably hydrochloric acid from the salt-cake process and sulphur compounds both from the manufacture of sulphuric acid and, especially, from the waste from the black-ash alkali process, were at first allowed to escape into the atmosphere in undesirable quantities, with serious consequences to vegetation within a considerable radius of the works. In the earlier years of development the wastefulness of inefficient recovery of such by-products, most of which possessed commercial value, seems not to have been sufficiently considered: but the economic consequences were two-fold. Not merely was the loss of chemical products to a large extent unnecessary and uneconomic ; but also the damage caused to the adjacent agricultural lands was even more serious. The alkali manufacturers themselves soon realized the position and, moved alike by their own interests and those of the neighbouring agricultural community, worked out procedures to minimize the troubles and also, as Dr. Hardie points out, gave their fullest assistance to the inquiry of a Select Committee set up by the House of Lords in $\mathbf{1 8 6 2}$ to consider the matter. In 1863, and again in 1875, Alkali Acts were passed to control the amounts of noxious gases permitted to escape to the atmosphere from chemical processes, and 'alkali inspectors' were appointed to see that the provisions of the Act were enforced. Dr. Hardie records that "the Alkali Act of 1863 imposed no burden on the alkali manufacturers", since the latter already had equipment in operation to safeguard the position: "all that the Act did impose was a stricter supervision of operating conditions". On the other hand, in his foreword Sir Frederick Bain says, "There is no burking the truth about the conditions of work in the early days, of the wastefulness and misuse of valuable materials. Today we must think these conditions dreadful; but we must remember also that it was the constant urge to improve those conditions, the increasing pursuit of new knowledge to overcome them, that made possible the modern scientifically controlled chemical industry".

A further unfortunate consequence, not peculiar to the Widnes district or indeed to purely chemical industries, was the inefficient combustion of fuel in steam-raising, etc., which has caused so much pollution of the atmosphere near industrial centres with smoke, soot and mineral ash. This also is gradually passing away, indeed has almost passed away as far as the modern large chemical manufacturing firms are concerned: for again, desire not to cause a nuisance and the need for the most efficient use of increasingly costly fuel work towards the same end. Nevertheless, as is well known, smoke pollution has been much more persistent than the chemical pollution of the atmosphere. Chemical pollution became negligible, except in isolated instances, by about 1880 or a little later; but even forty years ago, Widnes, for example, was hidden from view even on a bright day by a smoke pall. To-day, in similar conditions, a slight haze may be seen from a distance to cover the town, but the old black smoke veil has gone, we may hope, for ever.

Such is the story of Widnes. A locality perhaps (like other relatively flat regions of the English countryside) not markedly picturesque or beautiful, but a useful and profitable area for farming: an agricultural community seriously menaced at one time by pollution of vegetation by chemicals and by smoke; a rapidly developing chemical community responsible for the production of much of the heavy chemicals (alkalis, acids and others) needed in many British and foreign industries; and at last both agricultural and chemical interests able to operate in contiguity and without undue interference. In modern times, great chemical factories are developed in areas previously mainly agricultural without 'teething troubles' of the kinds which Widnes had to endure. The chemical processes are evolved in the laboratories and pilot plants of large organizations, often far distant from the site of the future factory. There is a minimum of dislocation and inconvenience to the adjacent countryside and its inhabitants, once the travail of eonstruction and building contraetors is at an end. From the point of view of general commercial prosperity it ought, indeed, in general to be advantageous to have a manufacturing unit set within a purely agricultural area, and this in the long run has happened in Widnes.

There remains the more impalpable but important matter of continuity in personal human relationships between employer and labourer, familiar in the farming industry, exemplified also in the chomical industry of Widnes in the past hundred years, but by no means invariably present in manufacturing industries. It is an important matter, even merely as one of good economics, and it is too valuable to be overlooked, as Dr. Hardie's book abundantly shows. Can it be preserved in the altered conditions of process-development in perhaps distant research and development centres, and direction and management at the higher levels also remote from the actual production centre? Let us hope so, for, as Sir Frederick Bain wrote, "This is the great fortune of Widnes".

T. P. Hitmiteh

\section{NUCLEAR DIVISION IN AMEBA AND ITS BEARING ON CLASSIFICATION}

\author{
By DR. B. N. SINGH
}

Department of Soil Microbiology, Rothamsted Experimental Station, Harpenden, Herts

I $\mathrm{N}$ the past, the order Amobida Calkins has been divided into families on such characters as the presence of a flagellate stage under certain physiological conditions, thoir parasitic or free-living nature, the possession of an accessory body called Neben. körper, etc. Such a system is not based on any reasonable theory of the evolution of the group of organisms called amœbæ.

The genera and species among the families of Amobida have been created by earlier workers largely on the nuclear structure and the mode of nuclear division. A number of memoirs dealing with this subject have appeared since the work of Vahlkampf $^{1}$. A careful study of these memoirs shows that conflicting views have been put forward by different workers who carried out cytological investigations. The karyosome, which should be called 'nucleolus' because it is Feulgen-negative, has been supposed to give rise partly or completely to chromosomal chromatin in some forms and not in others. The 'peripheral chromatin' has been stated to bo completely absent in some amøbæ and present 